\title{
Tadeusz Kononiuk
}

\author{
Uniwersytet Warszawski
}

\section{Genoteologia reportażu. Dyskurs wiedzy i wiary Genotheology of reportage. Discourse of knowledge and faith}

\begin{abstract}
ABSTRAKT
Tekst biblijny traktowany jako narracja od dawna jest przedmiotem badań w hermeneutyce biblijnej, których celem jest pełniejsze zrozumienie sensu biblijnego przekazu. Badania te prowadzone są z różnych perspektyw teoretycznych, metodologicznych i ideologicznych. Artykuł jest medioznawczą analizą treści Nowego Testament, odwołującą się bezpośrednio do teologii mediów. To teologiczno-medioznawcze podejście badawcze pozwoliło stworzyć autorską koncepcję genoteologii (terminu powstałego ze złożenia dwóch słów: genologii i teologii).

Umożliwia ona dualistyczną - genologiczną i teologiczną - heurezę ksiąg biblijnych, łącząc literaturoznawcze ramy narracyjne i praktyki dyskursywne, wykorzystujące metodologię genologiczno-medioznawczą z teologicznymi ramami narracyjnymi, skoncentrowanymi na aksjologicznej analizie przekazu biblijnego. Taka perspektywa badawcza pozwala na eksplorację tekstu biblijnego w wymiarze przedmiotowym (aspekty warsztatowe, gatunkowe, literackie) i wymiarze podmiotowym (aspekty aksjologiczno-deontologiczne), umożliwiając tym samym próbę odpowiedzi na pytanie, czy w Nowym Testamencie można odnaleźć korzenie gatunkowe reportażu i kanon aksjologiczny reportera.
\end{abstract}

SŁOWA KLUCZOWE

aksjologia, deontologia, etos reportera, genologia, medioznawstwo, praktyki dyskursywne, ramy narracyjne, reportaż, tekst biblijny, teologia

\section{ABSTRACT}

Biblical text, regarded as a narrative, has long been the subject of research in biblical hermeneutics, which aims to better understand the meaning of biblical transmission. This research is conducted from different theoretical, methodological and ideological perspectives. The article is a media analysis of the content of the New Testament, referring directly to the theology of the media. It was this theological and media-media-scientific approach that led to the development of the author's concept of genotheology. (a term created by two words: genology and theology). It enables the dualistic - genological and theological - heuresis of biblical books by combining a literature narrative framework and discursive practices, using a geneological-mediaological methodology with a theological narrative framework focused on axiological analysis of biblical transmission. Such a research perspective makes it possible to explore biblical text in the subject dimension (workshop, genre, literary aspects) and subjective dimension (axiologicaldeontological aspects), thus enabling an attempt to answer the question whether the genre roots of reportage and the axiological canon of the reporter can be found in the New Testament?

\section{KEYWORDS}

axiology, biblical text, deontology, discourse practices, genology, media science, narrative framework, reportage, reporter's ethos, theology 
nauce, podobnie jak w ogóle w życiu, pojawiają się pytania, na które trudno znaleźć jednoznaczną odpowiedź, ale jednocześnie fascynują one swoją symboliką i oryginalnością.

W medioznawstwie za taki fenomen można uznać monografię Biblia a korzenie reportażu. Glosa do historii i teorii gatunku, autorstwa wybitnego teoretyka reportażu Kazimierza Wolnego-Zmorzyńskiego, w której autor stawia właśnie takie trudne pytania:

- czy Ewangelie można uznać za prototyp reportażu, w którym nie ma miejsca na fikcję, a dominuje w nich sprawozdawstwo i opisywanie postaci Jezusa, Jego życia i Dobrej Nowiny, jaką zwiastował?

- czy to proste sprawozdawstwo Ewangelistów - pisali jak potrafili - sprawiło, że powstał faktograficzny zapis rzeczywistości, w której żyli? ${ }^{1}$

Pytania te mają fundamentalne znaczenie nie tylko w medioznawstwie, dotyczą bowiem prawd uniwersalnych ważnych w życiu nie tylko reportera, ale także każdego człowieka, są one nośnikiem wiedzy i wyobrażeń o rzeczywistości, dyskursem wiary i wiedzy wpływającym na nasz sposób myślenia i postępowania. Artykuł jest próbą naukowej refleksji nad tymi pytaniami na gruncie nauki o mediach.

\section{KIERUNEK INTERPRETACJ}

Ranga i waga tych pytań stawia w centralnym punkcie refleksji nie tylko problematykę reportażu jako gatunku, lecz także zagadnienie postaw ludzkich wobec zachodzących zjawisk, kwestie wyboru motywacji postępowania, hierarchii wartości, stylu życia. Wszystkie te problemy mają decydujące znaczenie w kształtowaniu złożonej semantyki nowoczesności, ponieważ podlegają działaniom wielu potężnych sił, powodujących nieustanny ruch, nieustanne przeobrażenia, pozbawiając system aksjologiczny jednostki wszelkich oczywistych treści².

W jakich więc ramach teoretycznych można usytuować problemy badawcze zawarte w pierwszym pytaniu: czy twórczość autorów Nowego Testamentu

${ }^{1}$ K. Wolny-Zmorzyński, Biblia a korzenie reportażu. Glosa do historii i teorii gatunku, Toruń 2020, s. 79.

${ }^{2}$ Por. P.A. Soukup, Communication and Theology: Introduction and Review of the Literature, London 1983. 
można przyrównać do pracy współczesnych reporterów? I w pytaniu drugim: czy w Nowym Testamencie można odnaleźć korzenie gatunkowe reportażu i kanon aksjologiczny reportera?

\section{METODA}

Te wstępne założenia badawcze należy więc uzupełnić kilkoma uwagami dotyczącymi metody czy też rozwiązań teoretycznych, które pozwolą na udzielenie odpowiedzi na postawione pytania.

W podejmowanych rozważaniach rudymentarne znaczenie ma wyjaśnienie i uściślenie tytułu artykułu: Genoteologia reportażu. Dyskurs wiary i wiedzy. Określa on bowiem nie tylko istotę rozwiązywanego problemu badawczego, lecz także autorską koncepcję metodologiczną traktowaną jako pewną formułę heurezy tekstu biblijnego, a także zawiera dwa założenia interpretacyjne.

Po pierwsze, tytuł Genoteologia reportażu ma religijne konotacje, nawiązujące bezpośrednio do teologii mediów ${ }^{3}$. Na tej teologiczno-medioznawczej idei zbudowana została autorska koncepcja genoteologii. Pojęcia powstałego ze złożenia dwóch słów i dwóch dyscyplin badawczych: genologii i teologii ${ }^{4}$. Termin genoteologia oznacza w proponowanym tu ujęciu kategorię badawczą, w której połączono opisane na gruncie literaturoznawczym ramy narracyjne oraz praktyki dyskursywne, obecne w teoriach genologiczno-medioznawczych, z ramami narracyjnymi znanymi naukom teologicznym, skoncentrowanymi na aksjologicznej analizie przekazu biblijnego.

Genoteologia jako interdyscyplinarna koncepcja badawcza umożliwia tym samym dualistyczną - przedmiotową i podmiotową - eksplorację tekstu biblijnego".

Genoteologia jako koncepcja badawcza umożliwia tym samym dualistyczną przedmiotową i podmiotową - eksplorację tekstu biblijnego.

Metodologia genologiczno-medioznawcza pozwala na analizę tekstu w wymiarze przedmiotowym, czyli koncentruje się przede wszystkim na aspektach: warsztatowym, gatunkowym, literackim itp.

${ }^{3}$ J.P. Hudzik, Wykłady z filozofii mediów. Podstawy nauk o komunikowaniu, Warszawa 2017, s. 364.

${ }^{4}$ Por. A. Kozieł, Genologia dziennikarska, „Studia Medioznawcze” 2013, nr 3; także K. Wolny-Zmorzyński, $O$ wybranych problemach dziennikarstwa: genologia i mistrzowie, Kielce 2009. 
Metodologia teologiczna natomiast jest $\mathrm{w}$ większym zakresie podmiotową kategorią interpretacyjną, mającą wymiar aksjologiczno-deontologiczny, na którym zbudowany jest etos reportera ${ }^{5}$.

Po drugie, genoteologia, jako proponowana tu kategoria badawcza, pozwala uwzględnić w egzegezie zarówno praktyki dyskursywne, jak też ramy interpretacyjne. Przy czym opis praktyk dyskursywnych wymaga podejścia interdyscyplinarnego, w którym możliwa jest analiza pozajęzykowych kontekstów mówienia: przedmiot zainteresowań lingwistyki jest zarówno przedmiotem refleksji teologicznej, ale też pozostaje w kręgu zainteresowań badań genologicznych, medioznawczych czy jednocześnie przynależy do pola badań z zakresu etyki, historii itp.

Michel Foucault, nawiązując do takiego definiowania dyskursu, wskazał, że służy on analizie nie tylko języka, lecz także przestrzeni aksjologiczno-epistemologicznej, w której funkcjonuje reporter ${ }^{6}$. Dyskurs sprawia, że możemy odnaleźć porządek w tym, co pozornie może sprawiać wrażenie nieregularności i chaosu ${ }^{7}$. Stąd też istotnym elementem teorii dyskursu jest czynnik mentalny uruchamiający mechanizmy poznawcze i emocjonalne - dyskurs wiary i wiedzy - definiujący wartości, zasady, reguły istotne w życiu jednostek (np. reporter), jak i funkcjonowaniu struktur społecznych (np. środowisko medialne) ${ }^{8}$.

Konkurujące ze sobą dyskursy przenikają wszystkie obszary genoteologii, umożliwiając badanie i analizowanie zróżnicowanych treści biblijnych zarówno historycznych, jak i symbolicznych oraz specyficznych dla nich form i środków wyrazu. W takim podejściu badawczym ma też zamocowanie merytoryczne podział tekstów biblijnych na gatunki literackie, dopuszczające fikcję, i gatunki dziennikarskie - reporterskie, dokumentujące rzeczywistość, będący jeszcze jedną egzemplifikacją dyskursu wiary i wiedzy ${ }^{9}$.

Ramy interpretacyjne, jako narzędzie badawcze, umożliwiają całościową egzegezę tekstu biblijnego, definiują bowiem problemy, diagnozują przyczyny,

${ }^{5}$ T. Kononiuk, Rzetelne dziennikarstwo. Aksjologia i deontologia, Warszawa 2018, s. 23-50.

${ }^{6}$ M. Foucault, Archeologia wiedzy, tłum. A. Siemek, Warszawa 1977, s. 77.

${ }^{7}$ Por. T.A. van Dijk (red.), Dyskurs jako struktura i proces, tłum. G. Grochowski, Warszawa 2001; a także J. Szacki, Historia myśli socjologicznej, Warszawa 2002, s. 905-906.

${ }^{8}$ Por. T. Kononiuk, Etyczne dziennikarstwo. Ewolucja deontyczna zawodu, Warszawa 2015.

${ }^{9}$ Por. W. Misztal, M. Radej, R. Nęcek (red.), Jan Paweł II i komunikacja społeczna, Kraków 2020. 
wskazują konkretne źródła, odwołują się do kontekstu ${ }^{10}$. Dla realizacji procesu badawczego został autorsko zaadoptowany, zaproponowany przez Paula D’Angelo, paradygmat wykładni ram interpretacyjnych ${ }^{11}$. Ten zabieg metodologiczny pozwolił na eksplorację genoteologii reportażu w trzech aspektach, porządkując zarazem strukturę merytoryczną i formalną publikacji i wyodrębniając w niej trzy części:

- aspekt poznawczy - stanowiący studium tradycji badań tekstu biblijnego,

- aspekt konstruktywistyczny - analizujący narzędzia interpretacji treści biblijnych,

- aspekt krytyczny - umożliwiający ewaluację koncepcji badawczej Kazimierza Wolnego-Zmorzyńskiego.

\section{HIPOTEZA}

Jaką perspektywę poznawczą wyznacza zawarty w tytule problem? Czy rodzi sprzeczności, które mają decydujące znaczenie dla egzegezy tekstu biblijnego? Czy mamy do czynienia z konfliktem zasad i reguł stanowiących osnowę badań tekstu biblijnego zakorzenionymi w tradycji? Czy zaprzecza ona dotychczasowej metodologii badawczej, czy może wnosi nowe narzędzia badawcze?

Zdaniem autora genoteologiczna koncepcja metodologiczna i zaproponowane w niej instrumentarium badawcze umożliwia w dużo większym zakresie, dotychczas niestosowanym, weryfikację teorii bezbłędności Pisma Świętego czy też paradygmatu stanowiącego, że księgi biblijne pisane są pod natchnieniem Bożym i mają nie tylko ludzi, ale również Boga za autora i tym samym są wolne od błędów ${ }^{12}$.

Stąd też jako hipotezę publikacji przyjęto konieczność wykazania, że z perspektywy genoteologicznej i teorii bezbłędności Pisma Świętego, Nowy Testament, a zwłaszcza Ewangelie i Dzieje Apostolskie. można uznać za reportaż, ewangeliści bowiem przedstawiają życie Jezusa Chrystusa w sposób sprawozdawczy, a zawarte tam fakty i opisy zdarzeń oparte są na prawdzie.

${ }^{10}$ R.M. Entman, Framing: towards clarification of a fractured paradigm, ,Journal of Communication" 1993, vol. 43 (4), s. 51-58.

${ }^{11} \mathrm{P}$. D’Angelo, News framing as a multiparadigmatic research programme: a response to Entman, „Journal of Communication” 2002, vol. 52 (4), s. 870-888.

${ }^{12}$ S. Łach, Bezbłędność Pisma Świętego, w: F. Gryglewicz, R. Łukaszyk, Z. Sułowski (red.), Encyklopedia katolicka, t. 2, Lublin 1976, kol. 343-345. 


\section{TRADYCJA BADAŃ TEKSTU BIBLIJNEGO}

Wyraz 'Biblia' pochodzi z greckiego he biblos, rzeczownika zapożyczonego ze słownika egipskiego, gdzie oznaczał bądź papirus, z którego w starożytności wyrabiano materiał piśmienny, bądź 'świętą i czcigodną księgę'13.

Biblia zawiera opis zbawienia człowieka od prehistorii protoplastów rodzaju ludzkiego (Rdz. 1-3) aż do eschatologicznego wypełnienia się czasów (Ap). Uważana jest za natchnione objawienie Boże, stanowi nie tylko depozyt wiary i jej regułę, lecz jest także wyrazem świadomości ludu Bożego ${ }^{14}$.

Odtworzenie powstania Biblii jest niezwykle trudne. Dlatego też dla potrzeb artykułu metody badawcze zostaną zawężone tylko do tradycji badań Nowego Testamentu Wykorzystywane są do nich różne metody, do których zalicza się: historię form, historię tradycji oraz historię redakcji ${ }^{15}$.

Metoda historii form pozwala na wydobycie z Ewangelii i Listów najstarszych warstw i określenie okoliczności ich powstania.

Metoda historii tradycji umożliwia ustalenie drogi przekazów sięgających Jezusa historycznego, poprzez etap tradycji aż do ich ostatecznej redakcji.

Metoda zaś historii redakcji ukazuje, po dokonaniu analizy układu przekazanych materiałów, cel teologiczny danej księgi i jej kerygmatyczną wymowę.

Na tej podstawie w egzegezie biblijnej przyjęto pogląd, że kształtowanie się pism Nowego Testamentu obejmuje wstępny etap redakcyjny, w którym powstały pierwsze schematy oraz właściwy etap redakcyjny, w którym autorzy ksiąg włączyli je do redagowanych zbiorów. Na właściwym etapie redakcyjnym powstawały spisane fragmenty tradycji o Jezusie, z których nie wszystkie zachowały się. Główne schematy przepowiadania można odtworzyć przede wszystkim na podstawie Dziejów Apostolskich, zwłaszcza mów apostoła Piotra. Na tym etapie redakcyjnym zredagowano i włączono do poszczególnych ksiąg Ewangelii te fragmenty, które miały charakter kerygmatyczny, najbardziej zgodny z celem każdej z nich (J 20,31) ${ }^{16}$.

${ }^{13}$ J. Szlaga, Biblia, w: F. Gryglewicz, R. Łukaszyk, Z. Sułowski (red.), dz. cyt., kol. 377-379.

${ }^{14}$ Por. J. Kudasiewicz, Ze współczesnych badań literackich nad Ewangeliami, w: S. Sawicki, J. Gotfryd (red.), Biblia a literatura, Lublin 1986.

${ }^{15}$ F. Gryglewicz, Biblia. Nowy Testament, w: F. Gryglewicz, R. Łukaszyk, Z. Sułowski (red.), dz. cyt., kol. 384-385.

${ }^{16}$ H. Langkammer, Biblia. Redakcja, w: F. Gryglewicz, R. Łukaszyk, Z. Sułowski (red.), dz. cyt., kol. 386-389; a także B.J.F. Lonergan, Method in Theology, London 1972. 
Ewangelie stały się głównym świadectwem wiary o Jezusie, opartej na tradycji apostolskiej, odtwarzającej jego historię i działalność. Najważniejszym ogniwem łączącym pierwszy etap (słowa i czyny Jezusa) z ostatnim (redakcyjne zespolenie fragmentów tradycji przez ewangelistów) jest apostolska tradycja. W tej fazie dokonało się autorytatywne przekazanie apostolskich świadectw o Jezusie następnej generacji i wtedy zaczęto tłumaczyć je z języka aramejskiego na grecki ${ }^{17}$.

Księgi Nowego Testamentu powstały jako teologiczna refleksja nad życiem Jezusa w świetle jego zmartwychwstania (Ewangelie) oraz jako zbawcza interpretacja wydarzeń paschalnych (Listy, Dzieje Apostolskie) w celu dostosowania kerygmatu Jezusa i o Jezusie do konkretnych potrzeb Kościoła ${ }^{18}$.

W tradycji badań ksiąg Nowego Testamentu przyjmowano, że czyny Jezusa opisane w Ewangeliach, a także wszystkie przypisywane Jezusowi konkretne wypowiedzi, zwroty i poszczególne wyrażenia zostały w formie literalnej zapamiętane przez świadków jego działalności i nauczania. Wskazywano, że apostołowie nie mieli trudności z zapamiętywaniem cudów Chrystusa i różnych wydarzeń z jego życia i dokładnym przekazywaniem treści kerygmatu dzięki specyficznemu żydowskiemu stosunkowi ucznia do mistrza ${ }^{19}$.

Jako kryterium autentyczności słów Jezusa przytaczano fakt, że w Kościele pierwotnym, będącym dobrze zorganizowaną społecznością, czuwano od początku nad poprawnością nauczania. Apostoł Piotr wizytował palestyńskie Kościoły, a Paweł głosił, że stronić należy od każdego, kto nie postępuje zgodnie z nauką Jezusa (2 Tes.3,6) W liście zaś do Galacjan pisał: „Ale gdybyśmy nawet my lub anioł z nieba głosił wam Ewangelię, różną od tej, którą wam głosiliśmy - niech będzie przeklęty" (Gal.1,8 BT). Nauka Jezusa nie była tylko zwykłym jednorazowym zdarzeniem, lecz miała być regułą życia dla wszystkich ludzi.

W ciągu wieków powstało wiele metod i kryteriów, dzięki którym można dotrzeć do autentycznych słów Jezusa i jego nauczania. Dorobek tych studiów jest obszerny $^{20}$, a jego dokładne omówienie wykracza poza cel badawczy tego artykułu, który skoncentrowany jest przede wszystkim na poszukiwaniu w Ewangeliach korzeni gatunkowych reportażu.

${ }^{17}$ Por. E. Dąbrowski, Ewangelie. Ich powstanie i rodzaj literacki, Niepokalanów 1949.

${ }^{18}$ A. Świderkówna, Rozmowy o Biblii. Nowy Testament, wyd. 5, Warszawa 2018, s. 10-11.

${ }^{19}$ L. Stachowiak, Biblijny styl, w: F. Gryglewicz, R. Łukaszyk, Z. Sułowski (red.), dz. cyt., kol. 492-493.

${ }^{20}$ Por. B.J.F. Lonergan, dz. cyt. 
W tym obszarze badań tekstu biblijnego nowe koncepcje metodologiczne pojawiły się na przełomie XIX i XX wieku za sprawą Marie-Josepha Lagrange'a. W 1902 roku wygłosił on na uniwersytecie w Tuluzie serię wykładów poświęconych różnym formom wyrazu wykorzystywanym przez natchnionych autorów ksiąg biblijnych. Te zróżnicowane formy wyrazu nazwał teorią biblijnych rodzajów literackich ${ }^{21}$. Lagrange twierdził, że autorzy natchnieni mogli korzystać z różnych źródeł. Stosownie do zamierzonego celu mogli pisać zarówno dzieła historyczne, jak i opowiadania dydaktyczne, w których szczegół stanowi tylko zewnętrzną szatę, nieprzedstawiającą wartości historycznej, ale w jakiś sposób wyrażającą prawdę poznaną pod natchnieniem Bożym ${ }^{22}$.

Lagrange twierdził, że autorzy natchnieni mogli korzystać z różnych źródeł. Stosownie do zamierzonego celu mogli pisać zarówno dzieła historyczne, jak i opowiadania dydaktyczne, w których szczegół stanowi tylko zewnętrzną szatę, nieprzedstawiającą wartości historycznej, ale w jakiś sposób wyrażającą prawdę poznaną pod natchnieniem Bożym

Teoria rodzajów literackich wykorzystywana była zwłaszcza w egzegezie biblijnej, krytyce literackiej tekstu biblijnego, natchnienia Pisma Świętego. Była narzędziem wykorzystywanym dla uwiarygodnienia treści biblijnych w konfrontacji z najnowszymi wynikami badań nauk przyrodniczych, historycznych, literackich ${ }^{23}$. Była często stosowana łącznie z teorią bezbłędności Pisma Świętego opartej na paradygmacie, że księgi biblijne napisane są pod natchnieniem Bożym i mają nie tylko ludzi, ale również Boga za autora i tym samym są wolne od błędów ${ }^{24}$.

${ }^{21}$ Por. K. Romaniuk, Z jakimi gatunkami literackimi mamy do czynienia $w$ Biblii, w: tegoż (red.), Czas na Biblię, Kraków 2013.

${ }^{22}$ Por. tenże, Wprowadzenie do krytyki tekstu Starego Testamentu i Nowego Testamentu, Poznań 1975.

${ }^{23}$ Por. P. Tillich, Systematic Theology, Chicago 1951.

${ }^{24}$ S. Łach, dz. cyt., kol. 343-345. 
W teorii biblijnych rodzajów literackich wyróżniono następujące rodzaje tekstów:

- teksty poetyckie: zalicza się do nich pieśni, modlitwy, hymny, lamentacje, pieśni dziękczynne, pokutne lub opiewające zwycięstwo, psalmy królewskie;

- teksty prawne są to różnego rodzaju formuły, dekalogi, zbiory praw;

- teksty kultowe, czyli formuły, rytuały, przepisy;

- teksty prorockie: należą do nich ostrzeżenia, groźby, przepowiednie;

- teksty historyczne: są to sagi, legendy, mity, bajki, anegdoty, przypowieści, opowiadania historyczne, opowiadania o czynnościach symbolicznych, roczniki, spisy, biografie, a nadto mowy, kazania, przemówienia sądowe;

- księgi sapiencjalne: zawierają one pozdrowienia, życzenia, błogosławieństwa i przekleństwa, formuły magiczne, przysłowia, sentencje, aforyzmy, zagadki $^{25}$.

W Nowym Testamencie biblijne rodzaje literackie oddzielnie wykorzystuje się egzegezy Ewangelii i oddzielnie do innych pism nowotestamentowych. W Ewangeliach synoptycznych wyróżnia się słowa Jezusa (logia Jezusa) i opowiadania o nim. W samych logiach zaś - słowa o charakterze proroczo-apokaliptycznym, przypowieści, sentencje, polecenia, słowa, którymi Jezus określał sam siebie („Jam jest...”) i mówił o swojej przyszłości, a ponadto apoftegmaty i dyskusje.

W opowiadaniach o Jezusie - opowiadania o cudach oraz opowiadania, których celem jest rozbudzanie wiary, a ponadto które relacjonują mękę Jezusową ${ }^{26}$.

Oddzielnym rodzajem literackim jest Ewangelia Jana, posługująca się specyficznymi środkami wyrazu ${ }^{27}$.

To wybiórcze, pełne skrótów myślowych i uproszczeń omówienie tradycji badań tekstu biblijnego, ma odsłonić pewien horyzont rozumienia i interpretacji ksiąg Nowego Testamentu, na którym można analizować genoteologię reportażu.

${ }^{25}$ H. Markiewicz, Zawartość narracyjna i schemat fabularny, w: tegoż, Wymiary dzieła literackiego, Kraków 1984, s. 102-103.

${ }^{26}$ F. Gryglewicz, Biblijne rodzaje literackie, w: F. Gryglewicz, R. Łukaszyk, Z. Sułowski (red.), dz. cyt., kol. 481-483

27 Tamże, kol. 481-482. 
Genoteologiczne narzędzia interpretacji tekstu umożliwiają dualistyczną, przedmiotową i podmiotową, heurezę treści biblijnych, wykorzystując w procesie badawczym praktyki dyskursywne i ramy interpretacyjne ${ }^{28}$.

Dyskurs jest narzędziem badawczym spajającym w nierozerwalną całość:

- działania komunikacyjne, czyli swoiste dla Biblii praktyki i sposoby posługiwania się językiem werbalnym i niewerbalnym, konwencje gatunkowe, za pomocą których natchnieni autorzy opisują rzeczywistość i usiłują wpływać na zachowania innych ludzi (lokucja);

- modele mentalne, traktowane jako sposoby rozumienia i interpretacji opisywanych przez Ewangelistów zdarzeń oraz nadawanie im znaczeń dla ich odbiorców, ale zarazem wpisując te zdarzenia i znaczenia (illokucja) w ogólniejsze wyobrażenia i wiedzę kreującą treść Chrystusowej kerygmy;

- interakcje, badające reakcję jednostek i społeczności na treść biblijnego przekazu oraz kształtujące ogólne ramy ładu społecznego wspólnot religijnych objętych dyskursem ${ }^{29}$.

W tym procesie łączenia działań komunikacyjnych, mentalnych i interakcji dyskurs powoduje, że każdy z tych elementów aktywizuje pozostałe, a wszystkie razem współtworzą świat metafizyczny człowieka zbudowany na fundamencie wiary i wiedzy. które stają się źródłem determinującym sposób myślenia i postępowania człowieka. „Wiara i rozum są jak dwa skrzydła, na których duch ludzki unosi się ku kontemplacji prawdy" - pisał Jan Paweł II w encyklice Fides et ratio.

Dyskurs wiary i wiedzy obecny jest we wszystkich obszarach genoteologii, umożliwiając eksplorację zróżnicowanych treści biblijnych, zarówno historycznych, literackich, jak i symbolicznych. Takie podejście badawcze pozwoliło na dychotomiczny podział treści biblijnych na gatunki literackie dopuszczające treści symboliczne i gatunki dziennikarskie, w tym także reportażowe, dokumentujące wydarzenia historyczne.

${ }^{28}$ D. McQuail, Teoria komunikowania masowego, tłum. M. Bucholc, A. Szulżycka, red. nauk. T. Goban-Klas, Warszawa 2012, s. 99, 219.

${ }^{29}$ M. Mrozowski, Przenikanie mediów. Ewolucja mediów a przemiany ładu społecznego, Warszawa 2020, s. 60-63. 
W ramach gatunków reportażowych w Ewangelii można, za Kazimierzem Wolnym-Zmorzyńskim ${ }^{30}$, wyróżnić zróżnicowane subkategorie reportażu, takie jak:

- teksty biblijne mające korzenie gatunkowe reportażu ${ }^{31}$,

- teksty biblijne posiadające elementy reportażu ${ }^{32}$,

- teksty biblijne o charakterze reportażu retrospektywnego ${ }^{33}$,

- teksty biblijne będące prototypem reportażü

Ta specyfikacja subkategorii reportażu biblijnego nawiązuje do teorii bezbłędności Pisma Świętego stanowiącej, że treści biblijne zawierają autentyczne słowa Jezusa i są wolne od błędów, a zatem można stwierdzić, iż:

- Ewangelie mówią o zdarzeniach historycznych i prawdziwych ${ }^{35}$

- Ewangelie są dokumentem zawierającym prawdziwe szczegóły z życia Jezusa $^{36}$

- autorzy Ewangelii byli wiernymi rejestratorami rzeczywistości ${ }^{37}$.

Uwzględniając powyższe przesłanki, można zatem skonstatować, że autorzy Ewangelii mówią prawdę, podają rzetelne zbadane i sprawdzone fakty ${ }^{38}$, tym samym Ewangelie mają wszystkie cechy reportażu,

Z taką autorską kategoryzacją reportażu biblijnego Wolnego-Zmorzyńskiego polemizuje Wojciech Furman, wskazując na jej pewne niekonsekwencje metodologiczne, wynikające, jego zdaniem, z niemożności weryfikacji prawdziwości przekazywanych w Ewangeliach faktów i zdarzeń ${ }^{39}$. Genoteologia i wykorzystywane w niej praktyki dyskursywne pozwalają na eliminowanie takich dylematów badawczych, przestrzeń epistemologiczna, w której żyli i tworzyli autorzy biblijni, umożliwiała im bowiem łączyć w nierozerwalną całość elementy symboliczne i historyczne, uwiarygodniające ich przekaz.

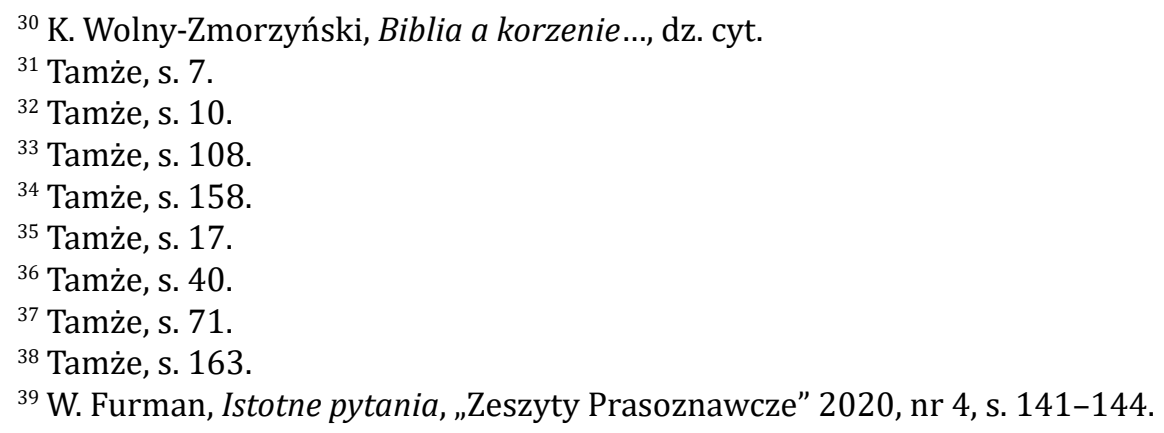


Dla wsparcia swojej argumentacji Furman wskazuje za Leszkiem Kołakowskim $^{40}$, dwie kategorie wiedzy: wiedzę technologiczną i wiedzę mityczną. Wiedza technologiczna wynika z empirycznego poznania i stale jest weryfikowana przez nowe doświadczenia i odkrycia.

Wiedza mityczna zaś dotyczy kwestii ontologicznych będących poza granicami ludzkiego poznania.

Mimo że ramy znaczeniowe i interpretacyjne wiedzy mitycznej i wiedzy technologicznej różnią się w dyskursie naukowym, to są obecne i przenikają się w ludzkim życiu. Paradoksalnie ich współistnienie w życiu każdej osoby jest obligatoryjne i zarazem fakultatywne, a wynikający z tego fenomenu konflikt wartości jest, zdaniem Kołakowskiego, istotą naszej kultury ${ }^{41}$.

\section{Wiedza technologiczna wynika z empirycznego poznania i stale jest weryfikowana przez nowe doświadczenia i odkrycia. Wiedza mityczna zaś dotyczy kwestii ontologicznych będących poza granicami ludzkiego poznania. Mimo że ramy znaczeniowe i interpretacyjne wiedzy mitycznej i wiedzy technologicznej różnią się w dyskursie naukowym, to są obecne i przenikają się w ludzkim życiu.}

Konkurujące ze sobą dyskursy eksplorują wszystkie obszary zarówno hermeneutyki biblijnej, jak i ludzkiej egzystencji, wpływając na sposób myślenia i postępowania człowieka. Pełnię władzy dyskurs osiąga wtedy, gdy ulega internalizacji, gdy zawarta w nim kerygma przenika do systemu wartości jednostki i zostaje przez nią uznana za obiektywną rzeczywistość. Kto potrafi przekonać innych do swojego dyskursu, ten ma nad nimi władzę - władzę symboliczną - a nasze posłuszeństwo tej władzy jest dobrowolne, bo ufamy, wierzymy, ba, jesteśmy pewni, że

\footnotetext{
${ }^{40}$ Por. L. Kołakowski, Obecność mitu, Warszawa 2003.

${ }^{41}$ Por. tegoż, Kultura i fetysze, Warszawa 2000.
} 
jest ona w stanie zapewnić nam dobroć i łaskę Bożą (Ps. 23). Aby jednak w ogóle dyskurs wiary odegrał ${ }^{42}$ jakąkolwiek rolę, najpierw musi być zrozumiany i zaakceptowany przez tych, do których jest kierowany.

Genoteologiczne narzędzia interpretacji tekstu biblijnego są propozycją badawczą, która ma przekonać, że treści Nowego Testamentu oparte są na wiedzy historycznej, a ich autorzy „badali dokładnie wszystko od początku” (Łk 1,1-3), a przekazywane „świadectwo jest prawdziwe” (J 21,24-25), tym samym spełnia wymogi gatunkowe reportażu.

\section{GENOTEOLOGIA WEDŁUG WOLNEGO-ZMORZYŃSKIEGO}

Genoteologia ontologicznie jest przełamaniem schematów badawczych tekstu biblijnego. Gdyby szukać w literaturze medioznawczej i teologicznej inspiracji dla takiego podejścia badawczego, to można by wskazać monografię Kazimierza Wolnego-Zmorzyńskiego Biblia a korzenie reportażu. Glosa do historii i teorii gatunku. Jest to książka wyjątkowa i szczególna, nie jest ona bowiem o tym, co myślą inni, ale jest pomyślana jako dzieło całkowicie autonomiczne. Tę jej autonomiczność podkreśla już sam tytuł pracy, ponieważ determinuje on zarówno jej treść, jak i zastosowaną metodę badawczą.

Inspiracją twórczą do jej napisania stały się dla Wolnego-Zmorzyńskiego słowa apostoła Pawła zawarte w liście pasterskim do skonfliktowanych wierzących w Koryncie: „Tak więc nie zależąc od nikogo, stałem się niewolnikiem wszystkich, aby tym liczniejsi byli ci, których pozyskam. (...) Dla słabych stałem się jak słaby, by pozyskać słabych. Stałem się wszystkim dla wszystkich, żeby w ogóle ocalić przynajmniej niektórych. Wszystko zaś czynię dla Ewangelii, by mieć w niej swój udział" (1 Kor. 9,19,22-23 BT). Wolny-Zmorzyński przyjmuje w swojej monografii zdecydowanie postawę Pawła, co potwierdza nie tylko jej tytuł, który nie jest jakąś arbitralną grą językową, ale determinantą integralnej filozofii badawczej autora. Traktuje on chrześcijańską wspólnotę czasów apostoła Pawła jako metaforę społeczności dziennikarskiej. W liście tym Paweł daje przykład swojej bezinteresownej miłości i troski o wiernych, apeluje do nich, aby przestrzegali określonego w kerygmie Chrystusowej systemu wartości. Wartości te, zdaniem Wolnego-Zmorzyńskiego, mają charakter uniwersalny. Są fundamentem nie tylko

${ }^{42}$ K. Wolny-Zmorzyński, Biblia a korzenie..., dz. cyt. 
etyki chrześcijańskiej, lecz także etyki dziennikarskiej, definiują ich tożsamość zawodową i wyjątkową rolę w społeczeństwie wynikającą z realizowanej przez nich profesjonalnej ideologii ${ }^{43}$.

Książkę Wolnego-Zmorzyńskiego można czytać, w aspekcie przedmiotowym, jako zupełnie autonomiczny wykład określonej teorii genologicznej zastosowanej do wykazania, że w tekstach biblijnych, zwłaszcza Nowego Testamentu, można dopatrzyć się cech współczesnych gatunków literackich i paraliterackich bądź korzeni reportażu. Ale można też czytać tę książkę inaczej, stosując genoteologiczne podejście badawcze jako rodzaj autorskiego zdefiniowania istoty dziennikarstwa. Potraktować tekst biblijny jako kanon aksjologiczno-deontologiczny reportera.

Wolnemu-Zmorzyńskiemu chodzi nie tylko o poszukiwanie w Ewangeliach korzeni gatunkowych reportażu, koncentruje się on bowiem przede wszystkim na wartościach etycznych i moralnych w pracy reportera. Wartości etyczne dotyczą tej części ludzkiej godności, która wiąże się z dokonywanymi przez dziennikarzy wyborami w zakresie dobrego i godnego postępowania, wartości moralne zaś stanowią zespół norm wyznaczających nasz stosunek innych ludzi ${ }^{44}$. Praktyki dyskursywne wykorzystywane $\mathrm{w}$ genoteologii umożliwiają dualistyczna analizę: przedmiotowo-podmiotową tekstu biblijnego, wykazując wzajemne zależności między aspektami warsztatowymi a aspektami etyczno-moralnymi w pracy reportera.

Zarówno dla apostoła Pawła, jak i innych apostołów ich praca miała charakter powołania: „Paweł, sługa Chrystusa Jezusa, z powołania apostoł, przeznaczony do głoszenia Ewangelii Bożej" (Rz 1,1 BT). Powołanie zawiera moment wezwania - vocatio - które zarówno może znaczyć zaproszenie do czegoś, jak i aktywność, np. głoszenie Ewangelii, służbę społeczeństwu wiążącą się z nałożeniem obowiązku ${ }^{45}$. Wezwanie jest zawsze skierowane przez kogoś do kogoś. Stronami tych relacji w przypadku Pawła był Chrystus, który powołał go do głoszenia Ewangelii Bożej, stronami zaś w przypadku dziennikarzy jest społeczeństwo, a powołanie oznacza obowiązek rzetelnego informowania. Powołanie zatem jest

${ }^{43}$ T. Kononiuk, Profesjonalizacja $w$ dziennikarstwie. Między modernizmem a ponowoczesnością, Warszawa 2013, s. 12.

${ }^{44}$ Tenże, Rzetelne dziennikarstwo..., dz. cyt., s. 23-50.

45 Tamże, s. 203-213. 
służbą wartościom, a ich realizacja staje się dla dziennikarza obowiązkiem. Obowiązek ten, świadczący o autentyczności powołania dziennikarza, utożsamiany jest z jego odpowiedzialnością ${ }^{46}$.

Odpowiedzialność jest najbardziej osobistą i niezbywalną z ludzkich wolności i najcenniejszym z ludzkich praw. Odpowiedzialność jest swoistym misterium, aktem samostanowienia reportera jako istoty moralnej podejmującej pełnienie wielorakich ról społecznych. A ciężar odpowiedzialności jest najwyższym dostojeństwem, jaki posiada istota ludzka, jej tożsamość poczyna się bowiem właśnie $\mathrm{z}$ odpowiedzialności. $\mathrm{W}$ akcie nadania takiego sensu odpowiedzialności rodzi się moja wolność moralna ${ }^{47}$.

\section{Odpowiedzialność jest najbardziej osobistą i niezbywalną z ludzkich wolności i najcenniejszym z ludzkich praw. Odpowiedzialność jest swoistym misterium, aktem samostanowienia reportera jako istoty moralnej podejmującej pełnienie wielorakich ról społecznych.}

Zakresy obszaru moralnego imperatywu odpowiedzialności, ale i zarazem obszaru wolności moralnej nakładają się na siebie, tworząc swoistą bliskość. Sens absolutny i właściwy bliskości zakłada po prostu człowieczeństwo, a odpowiedzialność w stanie bliskości staje się bezwarunkowa - w dbałości o dobro drugiego człowieka, o poprawne odczytanie jego potrzeb. Aby być odpowiedzialnym $\mathrm{w}$ sposób odpowiedzialny, muszę wiedzieć, czego te potrzeby dotyczą, muszę wiedzieć, co służy jego interesom. Odpowiedzialność to obowiązek, obowiązek kojarzy się z wysiłkiem, którego efektem jest dbałość o człowieka, działanie na jego rzecz, w imię jego dobra ${ }^{48}$. Konsekwencją odmowy

${ }^{46}$ Z. Bauman, Etyka ponowoczesna, tłum. J. Bauman, J. Tokarska-Bakir, Warszawa 1996, s. 64-72; D. McQuail, dz. cyt., s. 215-217.

${ }^{47}$ T. Kononiuk, Etyczne dziennikarstwo..., dz. cyt. s. 165-167; E. Levinas, Freedom and Command, w: tegoż, Collected Philosophical Papers, Pittsburgh, Pa. 1998, s. 178.

${ }^{48}$ M.S. Pritchard, On Becoming Responsible, Lawrence, Kan. 1991, s. 10. 
podjęcia odpowiedzialności za drugiego człowieka staje się nieznośne milczenie odpowiedzialności ${ }^{49}$.

\section{Aby być odpowiedzialnym w sposób odpowiedzialny, muszę wiedzieć, czego te potrzeby dotyczą, muszę wiedzieć, co służy jego interesom. Odpowiedzialność to obowiązek, obowiązek kojarzy się z wysiłkiem, którego efektem jest dbałość o człowieka, działanie na jego rzecz, w imię jego dobra.}

Rozważania dotyczące aspektów aksjologiczno-deontologicznych pracy reportera Kazimierz Wolny-Zmorzyński rozwija w ostatniej części swojej monografii. Mimo że stanowi ona zaledwie 7 proc. jej zawartości, to jednak jest to jej efekt finalny, wszystkie pozostałe części są jakby drogą dojścia do tego ostatecznego rezultatu. Jak mawiali starożytni Rzymianie w czasach apostolskich, „finis coronat opus", tak też jest w przypadku książki Wolnego-Zmorzyńskiego, jej zakończenie wieńczy jego dzieło i pozwala dopiero ocenić je w pełni.

Genoteologia, według Wolnego-Zmorzyńskiego, w warstwie genologicznej jest szkołą pisania. W Biblii bowiem „używa się tych najprostszych słów: ziemia, niebo, morze, woda, człowiek, chleb, wino. One są wieczne, te najprostsze słowa, one są niezmienne" 50 , spełniają wszystkie cechy reportażu. W warstwie zaś teologicznej ewangeliści uczą współczesnego reportera, co jest dobre, a co złe, uczą dostrzegania dobra w drugim człowieku.

\section{PODSUMOWANIE}

Genoteologia reportażu jest ontologicznie próbą przełamania schematów teoretyczno-metodologicznych i może być traktowana jako zwrot hermeneutyczny

${ }^{49}$ Z. Bauman, dz. cyt., s. 106-109.

${ }^{50}$ Za: W. Giełżyński, Czterokrotnie rozstrzelany, „Ekspres Reporterów” 1978, nr 6, s. 38. 
w nauce o mediach i teologii, umożliwiający pełniejsze zrozumienie sensu biblijnego przekazu.

Cała koncepcja artykułu spięta jest klamrą części metodologicznej, definiującej koncepcję badawczą autora oraz części ostatniej uznającej aksjologię za metafizyczne jądro tożsamości zawodowej reportera, wskazując zarazem na immanentny związek między genologią i teologią. Koncepcja ta skonstruowana jest tak, by zwrócić uwagę na dualistyczny charakter pojęcia genoteologii umożliwiający przedmiotową i podmiotową heurezę tekstu biblijnego.

Analiza przedmiotowa proponuje odpowiedzi na pytania dotyczące m.in.: warsztatu reportera, specyfiki rodzajowej gatunków dziennikarskich, metod badawczych tekstu biblijnego, podziału treści biblijnych na historyczne i symboliczne, dziennikarsko-reporterskie i literackie itp.

Analiza podmiotowa natomiast zawiera kanon wartości i zasad konstytuujących ideologię zawodową reportera zamocowaną na imperatywie etycznej odpowiedzialności za siebie i moralnej za innych.

Paradygmat genoteologii tworzy zatem zarówno jej część warsztatowa, jak i aksjologiczna oparta na założeniu równej troski o warsztat i równego szacunku wobec wartości. Dla weryfikacji tych założeń badawczych w procesie analizy heurystycznej uwzględniono praktyki dyskursywne i ramy interpretacyjne umożliwiające interdyscyplinarną, pozajęzykową egzegezę kontekstów treści biblijnych. Służyło to przełamaniu epistemologicznego absolutyzmu w hermeneutyce biblijnej i pozwoliło na analizę nie tylko języka i uznanie Ewangelii za reportaż, lecz także przestrzeni aksjologicznej, w której funkcjonuje reporter. Istotnym elementem teorii dyskursu jest bowiem czynnik mentalny uruchamiający mechanizmy poznawcze i emocjonalne - dyskurs wiedzy i wiary. Stąd też można przyjąć, iż presupozycja zawarta w hipotezie artykułu stanowiąca, że dyskurs pełnię władzy osiąga wtedy, gdy ulega internalizacji i zakorzenia się w systemie wartości reportera, określając jego etos zawodowy, została zweryfikowana.

\section{BIBLIOGRAFIA}

Bauman Z., Etyka ponowoczesna, tłum. J. Bauman, J. Tokarska-Bakir, Wydaw. Naukowe PWN, Warszawa 1996.

D'Angelo P., News framing as a multiparadigmatic research programme: a response to Entman, „Journal of Communication” 2002, vol. 52 (4), s. 870-888.

Dąbrowski E., Ewangelie. Ich powstanie i rodzaj literacki, [s.n.], Niepokalanów 1949. 
Dijk T.A. van (red.), Dyskurs jako struktura i proces, tłum. G. Grochowski, Wydaw. Naukowe PWN, Warszawa 2001.

Entman R.M., Framing: towards clarification of a fractured paradigm, „Journal of Communication" 1993, vol. 43 (4), s. 51-58.

Foucault M., Archeologia wiedzy, tłum. A. Siemek, Państwowy Instytut Wydawniczy, Warszawa 1977.

Furman W., Istotne pytania, „Zeszyty Prasoznawcze” 2020, nr 4, s. 141-144.

Giełżyński W., Czterokrotnie rozstrzelany, „Ekspres Reporterów” 1978, nr 6.

Gryglewicz F., Biblia. Nowy Testament, w: F. Gryglewicz, R. Łukaszyk, Z. Sułowski (red.), Encyklopedia katolicka, t. 2, Towarzystwo Naukowe KUL, Lublin 1976, kol. 384-385.

Gryglewicz F., Biblijne rodzaje literackie, w: F. Gryglewicz, R. Łukaszyk, Z. Sułowski (red.), Encyklopedia katolicka, t. 2, Towarzystwo Naukowe KUL, Lublin 1976, kol. 481-483.

Hudzik J.P., Wykłady z filozofii mediów. Podstawy nauk o komunikowaniu, Wydaw. Naukowe PWN, Warszawa 2017.

Kołakowski L., Kultura i fetysze, Wydaw. Naukowe PWN, Warszawa 2000.

Kołakowski L., Obecność mitu, Prószyński i S-ka, Warszawa 2003.

Kononiuk T., Etyczne dziennikarstwo. Ewolucja deontyczna zawodu, Oficyna Wydawnicza ASPRA-JR, Warszawa 2015.

Kononiuk T., Profesjonalizacja $w$ dziennikarstwie. Między modernizmem a ponowoczesnościq, Oficyna Wydawnicza ASPRA-JR, Warszawa 2013.

Kononiuk T., Rzetelne dziennikarstwo. Aksjologia i deontologia, Oficyna Wydawnicza ASPRA-JR, Warszawa 2018.

Kozieł A., Genologia dziennikarska, „Studia Medioznawcze” 2013, nr 3, s. 23-34.

Kudasiewicz J., Ze współczesnych badań literackich nad Ewangeliami, w: S. Sawicki, J. Gotfryd (red.), Biblia a literatura, Wydaw. Tow. Naukowego KUL, Lublin 1986.

Langkammer H., Biblia. Redakcja, w: F. Gryglewicz, R. Łukaszyk, Z. Sułowski (red.), Encyklopedia katolicka, t. 2, Towarzystwo Naukowe KUL, Lublin 1976, kol. 386-389,

Levinas E., Freedom and Command, w: tegoż, Collected Philosophical Papers, Duquesne Univ. Press, Pittsburgh, Pa. 1998.

Lonergan B.J.F., Method in Theology, Darton, Longman and Todd, London 1972.

Łach S., Bezbłędność Pisma Świętego, w: F. Gryglewicz, R. Łukaszyk, Z. Sułowski (red.), Encyklopedia katolicka, t. 2, Towarzystwo Naukowe KUL, Lublin 1976, kol. 343-345.

Markiewicz H., Wymiary dzieła literackiego, Wydaw. Literackie, Kraków 1984.

McQuail D., Teoria komunikowania masowego, tłum. M. Bucholc, A. Szulżycka, red. nauk. T. Goban-Klas, Wydaw. Naukowe PWN, Warszawa 2012.

Misztal W., Radej M., Nęcek R. (red.), Jan Paweł II i komunikacja społeczna, Petrus, Kraków 2020.

Mrozowski M., Przenikanie mediów. Ewolucja mediów a przemiany ładu społecznego, PWN, Warszawa 2020.

Pritchard M.S., On Becoming Responsible, Univ. Press of Kansas, Lawrence, Kan. 1991.

Romaniuk K., Wprowadzenie do krytyki tekstu Starego Testamentu i Nowego Testamentu, Księgarnia Św. Wojciecha, Poznań 1975. 
Romaniuk K., Z jakimi gatunkami literackimi mamy do czynienia w Biblii, w: tegoż (red.), Czas na Biblię, Wydaw. M, Kraków 2013.

Soukup P.A., Communication and Theology: Introduction and Review of the Literature, World Association for Christian Communication, London 1983.

Stachowiak L., Biblijny styl, w: F. Gryglewicz, R. Łukaszyk, Z. Sułowski (red.), Encyklopedia katolicka, t. 2, Towarzystwo Naukowe KUL, Lublin 1976, kol. 492-493.

Szacki J., Historia myśli socjologicznej, Wydaw. Naukowe PWN, Warszawa 2002.

Szlaga J., Biblia, w: F. Gryglewicz, R. Łukaszyk, Z. Sułowski (red.), Encyklopedia katolicka, t. 2, Towarzystwo Naukowe KUL, Lublin 1976, kol. 377-379.

Świderkówna A., Rozmowy o Biblii. Nowy Testament, wyd. 5, Wydaw. Naukowe PWN, Warszawa 2018.

Tillich P., Systematic Theology, Univ. of Chicago Press, Chicago 1951.

Wolny-Zmorzyński K., Biblia a korzenie reportażu. Glosa do historii i teorii gatunku, Wydaw. Adam Marszałek, Toruń 2020.

Wolny-Zmorzyński K., O wybranych problemach dziennikarstwa: genologia i mistrzowie, Kieleckie Tow. Edukacji Ekonomicznej, Kielce 2009.

\section{Biogram}

Prof. dr hab. Tadeusz Kononiuk - kierownik Katedry Prawa Mediów na Wydziale Dziennikarstwa, Informacji i Bibliologii Uniwersytetu Warszawskiego, Press Fellow Wolfson College, Cambridge University, współtwórca Karty Etycznej Mediów, wieloletni członek Rady Etyki Mediów (1997-2010), biegły sądowy, ekspert sejmowy i senacki zajmujący się kodyfikacją prawa prasowego. Wykładał między innymi na Uniwersytecie Gdańskim, Katolickim Uniwersytecie Lubelskim, w Szkole Głównej Handlowej oraz Wyższej Szkole Dziennikarskiej im. Melchiora Wańkowicza. Prowadzi zajęcia i szkolenia warsztatowe z zakresu prawa prasowego i etyki dziennikarskiej dla studentów dziennikarstwa, dziennikarzy, praktyków PR, sędziów i prokuratorów. Autor książek i artykułów poświęconych procesowi profesjonalizacji i statusowi prawno-etycznemu dziennikarza i jego zawodowej odpowiedzialności, między innymi: Problemy prawne zawodu dziennikarskiego (współaut. Bogdan Michalski, Warszawa 1998), Profesjonalizacja $w$ dziennikarstwie. Między modernizmem a ponowoczesnościa (Warszawa 2013), Etyczne dziennikarstwo. Ewolucja deontyczna zawodu (Warszawa 2015), Rzetelne dziennikarstwo. Aksjologia i deontologia (Warszawa 2018), Fundamenty zawodu dziennikarza (współaut. Ksenia Kakareko, Jacek Sobczak (Poznań-Warszawa 2019).

ORCID: 0000-0002-7531-7024 